Meri Stojanova

etno_m@yahoo.com

\title{
Intermarriages - Crossing Political and Social Borders
}

\begin{abstract}
Stojanova Meri, Intermarriages - Crossing Political and Social Borders. „Poznańskie Studia Slawistyczne” 4. Poznań 2013. Adam Mickiewicz University Press, pp. 277-291. ISBN 978-83-232-2525-6. ISSN 2084-3011.

This paper analyses Macedonian - Albanian intermarriages in Macedonia in the last fifteen years i.e. their frequency, routes and patterns set in correlation with the social and traditional relationship that existed and still exists in both ,,sending” and ,receiving” communities. The foundation of such ,new” constructions as Macedonian - Albanian intermarriages, deconstruct some of the already established norms both on the nuclear - family level and on the local - community level and reshape or construct new norms and relations within families and local communities as well.
\end{abstract}

Keywords: intermarriages, matchmaking, migration, religion, Macedonia, Albania, individual changes, ethnic changes

The phenomenon of intermarriage is not a topic that has recently become fascinating. Not only in Macedonia but also in the last thirty years it has been studied worldwide. The main motivation behind this article is the lack of research that has been carried out into Macedonian-Albanian intermarriages, despite the fact that such unions have become very frequent in the Republic of Macedonia over the last fifteen years. Intermarriages between female Albanians from the northern part of Albania and male Macedonians from the western parts of Macedonia gained their popularity because of their largely increasing numbers, areas which were caught by these waves of events, as well as the increased media coverage ${ }^{1}$. The rea-

\footnotetext{
${ }^{1}$ M. Rukaj, „Between Albania and Macedonia: Patriarchal loves”, 29 September 2010, <http://www.balcanicaucaso.org/eng/Regions-and-countries/Albania/>, 18.10.2010; В. Цветаноски, Албански моми за Македонски ергени, Глобус, по. 43, 2008; Б. Зафирова, Сѐ поголем број мешани бракови во тетовско, „Вечер” 5.09.2006.
} 
sons for these frequent occurrences are numerous in both countries, and they are determined by many factors, such as changes in demography, social standards, political and economic conditions, traditional culture, family life and religious beliefs. All these factors influence the shaping of social norms and the social behaviour of individuals, within a smaller or wider community, thus shaping its ,ideal” and/or „real” behaviour. But discrepancies between the ,ideal” and actual or ,acceptable” behaviour of individuals within a social group, family or community always exist.

When we discuss migration, we can talk about its various aspects: motives, direction, numbers of migrants, their gender and age, duration of migrations and many more. Although there are differences in the approach and research methods used by different sciences, such as ethnography, ethnology, anthropology, geography, sociology, demography, economy, etc., to some extent they all interlace, interact and complement each other at some point, thus enriching our knowledge about people's reasons for moving and seeking something ,new and better”. In absence of scientific materials on the topic of intermarriages concerning the territory of Macedonia, the present study relies on field research data, theoretical literature and comparative analysis. During the field research the auto reflexive method was used to encompass the personal aspect of the informants and their perception of the causes for migrating and conditions in which they occur. The ethnographic method was used in order to prioritise the „truth" and the informants' ,point of view”.

Many intercontinental or transcontinental migrations have occurred through the centuries. Even though all migrants have been motivated by different factors, they all have one common goal: to provide a better life for themselves and/or their families. This condition can be correlated with Ernest George Ravenstein's oft-cited ,push and pull” factors and his Laws of Migration (1885), as complementary elements of migration. Much of the intense debate ${ }^{2}$ concerning migration that has taken place over recent decades has almost inevitably included multiculturalism, diversity, assimilation and ultimately the identity as an important but variable feature of people in contemporary society, thus taking mobility to be one of the essential means of functioning in the contemporary global society.

${ }^{2}$ S.P. Huntington, Who are we? The cultural core of American national identity, New York 2004, p. 7. 
Migration has also been directly or indirectly supported and encouraged by various relevant organizations and institutions, such as the European Union, which, through its agencies, accepts and encourages mobility ${ }^{3}$ (and very often we can say ,migration”) as one of the key factors in the realization of many of its activities, programmes and policies.

It is very important to mention the political factors, too. In many European countries, the collapse of the communist regime at the beginning of the 1990s initiated changes and transitions that were not only political, but economic and social as well. Dynamic transformations and disparities in many aspects of life caught people unprepared for the good and the bad things that were about to happen. The strong impact of these changes were about to be felt for many years to come.

Albania as a country entrapped into total isolation and under constant political and economic pressure, determined future development of the country with the opening of the borders, at the beginning of the 1990's. The fall of it's political borders led to great movement and migrations of people, inside and outside the country, thus causing far-reaching demographical imbalance that qualified Albania and Albanian immigration as one of the most dramatic demographic phenomenon's in Europe ${ }^{4}$. Daily and periodical migration, undertaken in order to secure basic existential needs, within the country ran parallel to the periodical migrations in the neighbouring countries, wider in Europe and worldwide. A large number of these periodical migrations, in time became permanent migrations.

The routes of internal migrations were directed from the rural to urban areas, as well as from the southern and northern parts of the country towards the central regions and lowlands, in the settlements along the active trade routes. This situation caused such a great increase in population in the capital city of Tirana that from 200000 inhabitants in 1990s' it reached the number of 800000 inhabitants in $2006^{5}$. According to 2001 census data ${ }^{6}$, the number

\footnotetext{
${ }^{3}<$ http://europa.eu/index_en.htm>, 15.11.2012.

${ }^{4}$ Population and Housing Census 2001.

${ }^{5}$ Ç. Erka, L.J.G. Van Wissen, Migration in the Albania of the post-1990s: triggered by post-communist transformations and facilitator of socio-demographic changes, „South-East Europe Review" no. 3, 2007, p. 88.

${ }^{6}$ A. Fetsi, F. Panzica, N. Popova, Labour Market Review of Albania, <http://www.etf. europa.eu/web.nsf/\%28RSS\%29/C125782B0048D6F6C12571250052A4EF?OpenDocument \&LAN=en>, 16.11.2012; Ç. Erka, L.J.G. Van Wissen, Migration in the Albania..., p. 94.
} 
of migrants who left the country since the beginning of the transition period in 1990's was about 1.000,000 Albanians, the largest percent of which belonged to the age group between 20 to 29 year olds. Male population ${ }^{7}$ constitutes about $70 \%^{8}$ of this population.

Main destinations of Albanian migrants were and still are Greece, Italy, USA, UK and Canada ${ }^{9}$. The small number of female migrants was usually a result of family reunions, in some cases for educational purposes and rarely their migration was the result of their personal decision.

In this same period the conditions in Macedonia were no less dramatic. Based on various statistical data available from the State Statistical Office of the Republic of Macedonia ${ }^{10}$, we could note that the migration processes are constant and in certain regions in western Macedonia the migration processes, whether they were internal or external migration, were most common among the female population aged 20-34. In some cases this ratio is several times higher than the rate of migration among the male population.

The migration rate of female population is particularly high in rural areas which bring demographic gender unbalances that lead to further social changes.

According to field research in mountainous villages of the ethnographic region of Porece, women refuse to remain ,peasant girls" all their life, and they are willing to migrate to the towns (Makedonski Brod, Kicevo, the city of Skopje etc.) and bare the risk, in order to find a job or to get married $^{11}$.

Despite the fact that in various documents Macedonia is mentioned as a transit destination of Albanian migrants heading to Greece or to other European countries, from the beginning of 1990s it has been observed that for a large number of women migrants Macedonia became their final destination. According to available statistical data the number of female immigrants from Albania was significantly higher than that of the male popu-

\footnotetext{
${ }^{7}$ INSTAT, Migration in Albania. Population and housing census 2001, Tirane 2001, p. 34.

${ }^{8}$ Ç. Erka, L.J.G. Van Wissen, Migration in the Albania..., p. 95.

${ }^{9}$ IOM, The Republic of Albania Migration Profile, <http://www.iom.hu/PDF/migration_profiles2007/Albania_2007.pdf>, 16.11.2012,p. 14.

${ }^{10}<\mathrm{http}: / /$ makstat.stat.gov.mk>, 16.11.2012.

${ }^{11}$ Narrative information from Prof. Aneta Svetieva from the field research in 2004.
} 
lation. Although this category of migrants has already been recognized by the Macedonian Government ${ }^{12}$, the concrete data on intermarriages which renders more detailed analysis is still missing.

Based on the religious believes we can perceive two emigrational waves of the female population from Albania. First wave of migrants involved Muslim female migrants that engaged in intermarriages with Muslim male population from Macedonia. But since the beginning of 2000 there has been a "shift" or "change" of population so Macedonia became a „wedding destination" for Christian Albanians ${ }^{13}$ from the northern parts of Albania.

The emergence of intermarriages can be identified under various terms, but the most appropriate terms would be ,wedding migrations" ${ }^{\text {"14 }}$ or „marriage migration” ${ }^{\text {. }}$. These terms have been adopted and accepted by many authors researching intermarriages. Interdependence that occurs in the creation of such social and family connections corresponds to the established traditional and cultural norms of the individuals and their countries, but also to the norms of the receiving country likewise.

Although during the field research the „lack" of male population ${ }^{16}$ in the concerning regions of Albania, was mentioned as an initial motive due to the intensive migration to European or transatlantic countries, we can conclude that the real motives were much more complex. Based on the research we can distinguish several main motives such as: economic, social, patriarchal relations and desire for gender equality, avoiding social marginalization etc.

${ }^{12}$ Влада на Република Македонија, Министерство за труд и социјална политика, Стратегија за интеграчија на бегалии и странщи во Република Македонија 20082015, Декември, 2008, p. 9.

${ }^{13}$ Е. Милошеска, Жената мигрант и акултураииските процеси преку обредноста на семејниот и на календарскиот ииклус, in: Batkański folklor jako kod interkulturowy, red. J. Rękas, t. 1, Poznań 2011, p. 281-288.

14 Л. Стојановиќ-Лафазановска, Миграчија и хабитус. Македонската емигращија во Германија, Скопје 2008, p. 29.

${ }^{15}$ L.A. Simons, Marriage, Migration and Markets: International Matchmaking and International Feminism, A Dissertation Presented to The Faculty of the Graduate School of International Studies University of Denver, June 2001, p. 47-50; A. Bruce, Making the Family - Marriage within and across Borders, <http://www.metropolis2009.org/Presentations/Marriage\%20A_Bruce_marriage_across\%20borders.pdf>, 15.10.2010.

${ }^{16}$ Field research 2010, 2012. 
When we discuss economic motives in many cases we are talking about young women coming from poorer families, families with a large number of children and families to whom the mediators ,present” a picture for „better” economic conditions in Macedonia, which basically does not always correspond to the reality.

Nevertheless this general attitude might be more a stereotype than a true reflection of the situation, because a lot of young women intermarried in Macedonia do not actually belong to the economically worse-off families than the ones they came into. Social conditions in Albania in the past have indirectly reflected on this category of population.

Namely according to their statements, the decision to leave their own country has been made ,easy” because of the population's fear of increased crime rate, and because of the danger to became victims of trafficking. According to the police reports and media in the Republic of Macedonia this fear is justified. From the visual media, daily and monthly press in the last 15 years, we are familiar with many cases of contemporary ,sexual slaves", especially in the region of western Macedonia, among which a large number come from Albania.

Strict patriarchal relations and norms, greatly contribute to the conclusion of intermarriages. We can conclude that, despite the confirmation of the young women that they have made the decision for intermarrying themselves, and without any pressure ${ }^{17}$, this decision comes ,in force” after the father or any other older male family member visits the home of the ,marriage candidate" and obtains information about his economic situation etc.

An important role in this context must be given to the image that the girls have about the situation and life in Macedonia, which is very idealistically presented by the „matchmakers” and it usually puts emphasis on the freedom of movement enjoyed by the female population which is unimaginable for the girls from Albania. According to their statements they have never, prior to their arrival to Macedonia, remained outside their homes in the evening. This condition might indicate the desire to acquire some kind of gender equality which is, in many cases, set in correlation with the decision to intermarry.

\footnotetext{
${ }^{17}$ Field research 2010, 2012.
} 
Existing social norms present in the respective regions, point to one more segment that we should take in consideration when determining the reasons for intermarrying. Frequent incidences of ,violent” events during the conclusion of interreligious marriages (among Catholic girls and Muslim boys), at the same time means breaking of the established norms and it faces condemnation. Thus, many of the girls referred to this phenomenon as a negative one and attributed it to the factors which contributed to their departure from Albania. Namely, social exclusion and marginalization that occur after the girl exceeds the appropriate „marriage age”, which is usually between 14 and 20 or 22 years old, represent an irreconcilable problem for many girls and their families which again dictates and facilitates the decision for departure.

I was 18 years old when my mother said to me: We will marry you. You are too old now. What are you going to do now? - They are used to marrying their daughters when they are 14 . My sister was 14 when they married her ${ }^{18}$.

Exposure to social ridicule and rejection is present in cases when after the engagement the fiancé leaves Albania to work abroad. After many years of absence in numerous cases it never comes to a conclusion of marriage, so the girls remain in a very disadvantaged position, without any opportunity to enter other marriage in the local community. According to this the only acceptable solution is to intermarry in another local community, even if it means marrying somebody with a different religion. The influence of traditional and social norms is apparent in the communities recipients. They can be perceived as a family structure where the sons are considered as pillars and continuants of the family tradition and thus they are „normatively” obliged to remain in the father's home.

In contrast the girls are expected to leave the parents' homes and live in a new environment. This social attitude to a large extent facilitates the decision to leave their father's home without any ,social sanctions" for the girls. This occurrence put in correlation with other factors contributes to the constant decrease of the female population in rural areas and it creates a gender misbalance, but in this case in favour to male population. Now, the male population is in a position of outnumbered population which leads to

\footnotetext{
${ }^{18}$ AEM K1-2009 Interview made by Eli Miloseska, 7.04.2009 in Prilep.
} 
deficit of „marriage candidates”. The maximum age limit suitable for the male population to get married is a bit higher and it ranges from 25 to 27 years. Exceeding this age limit, brings the qualification such as an „old bachelor", which again leads to expression of the social norms, so unmarried man are subjected to social exclusion and marginalization. In many cases within local communities they are perceived as incapable of forming their own homes and families, and rarely this situation is perceived as a juncture of circumstances. This general attitude and desire to belong to your own community in many cases facilitate the decision to conclude arranged marriage, even with a girl from another nationality. The field research confirms that all these marriages ${ }^{19}$ without any exception have been arranged through ,,matchmaking" ${ }^{20}$. Occurrence of matchmaking is not unknown or new in our or wider Balkan traditional cultures ${ }^{21}$. What is different is the way of its manifestation. Initiative for intermarriage is not realized through today's known marriage agencies, but it is concluded through some contemporary kind of traditional matchmaking. At the beginning of this migration wave, some Macedonians who had arranged marriages with Macedonian grooms played the role of matchmakers. They had their collaborators in Albania that appeared in capacity of interpreters and mediators with the Albanian girls. In time it came to a slight modification in the structure of matchmakers, so the once migrant Albanian women married in Macedonia, undertake the role of matchmakers. Thus ,the incoming bride" endeavours to create an ambience in which she will communicate with many of her friends and compatriots. This initiative can be followed according to the conclusion of new marriages. In this sense this situation can be observed as a "chain reaction” where the first ,marriage migrant”, directly or indirectly, starts to ,attract” and mediate the intermarriages between her female relatives or girlfriends from Albania and local male population from the ,new community” in Macedonia. Financial benefit of such mediation varies in the range of 500-1000 Euros. This amount is charged to the "groom” as soon as both candidates agree to a marriage. In many cases the girl's family does not receive any money and therefore

\footnotetext{
${ }^{19}$ Field research 2010, 2012.

${ }^{20}$ Field research 2010; Е. Милошеска, Жената мигрант и акултурациските проиеси...

${ }^{21}$ Л. Стојановиќ-Лафазановска, Миграција и хабитус..., р. 29.
} 
we cannot say that the marriage is concluded in order for the family to achieve economic benefit as is the case in many other countries ${ }^{22}$. However, the long lasting tradition of ,buying of the bride" through the newer forms of ,dowry" made its mark in the Macedonian - Albanian intermarriages. For example, all financial assets that are collected on the wedding or engagement ceremony, which almost in all the cases is obligatory first held in Albania and which is attended by all the bride's closest relatives and friends, the groom is obliged to leave them to the girl's family. When the matchmaker is a family member and after prior agreement, he may relinquish a certain amount of money to the girl's parents.

...my brother said: if you pay 1000 Euros I will let her come. Here, some of the girls that have just married here, in the village nearby (close to the village of Godivlje - author's note), her cousin said: if you give money you can take her ${ }^{23}$.

Although the ,purchase" of the bride is not generally perceived as something completely acceptable and understandable, in a direct discussion the girls try to avoid conversation on the topic, in many cases denying that the act actually happened.

The process of arranging a marriage consists of several consecutive stages. At first the ,groom to be" in accordance with someone's recommendation or based on his own initiative engages in contact with the matchmaker. After they reach the agreement for the amount of money needed to be paid for the mediation and acquaintance through photos, they come forward to arrange a „meeting” of the candidates. Once they principally choose the bride, together with the matchmaker and some of his friends or family members, they visit the house of the girl and meet her parents. After this first meeting, the father, brother or some other close male relative of the girl comes to Macedonia to meet the family of the groom, to see his house and property and to ,assess" whether he would be capable of taking care of the bride and the future family. Then he goes back to Albania and few days later they give their final decision, which is usually affirmative. The act of engagement or some kind of wedding ceremony is the next step. The groom accompanied by the members of his closest family goes to

${ }^{22}$ A. Bruce, Making the Family...

${ }^{23}$ AEM K1-2009 Interviews made by Eli Miloseska 3.03.2009 in the village of Krivogastani. 
Albania to take her from her (father's) home. On that occasion the groom gives the bride gold, a ring, earrings, a necklace and clothes, and after a short celebration in her home, the bride is taken to Macedonia. The main event - the wedding, is organized in Macedonia, according to the local traditions and customs which are accepted and undertaken by the bride without any objection and as a perfectly understandable thing. This is actually the girl's first step towards the process of integration and acculturation in the new community.

Although the locals approve of these types of marriages, emphasizing the moment of patriarchal values and obedience that distinguish the girls from Albania, still in everyday relations of the close family as well as the members of the local community, one can note some antagonism. In mutual communication the local population usually address them with the term „Albanki” (Albanian), which to some extend brings pejorative and disrespectful meaning. This attitude in some cases is present among some of the close family members, and this situation even leads to addressing the newborns with the term ,Albanians”, again with ironic connotation.

Almost all nuclear families created in this way have children in the first year of marriage, while in the next period they have at least one or two more. Since most of these marriages are concluded within the rural communities which are almost completely depopulated, the increased birth rates as a result of the increased number of newborn children, gets the approval of the local population and gives hope that many of the villages will be completely revitalized.

Intermarrying among the members of different ethnic, racial, social or religious groups is usually a difficult decision to make. Among all the above mentioned reasons religious believes of the spouses are probably the ones that provoke outmost discussion. If we consider religious tolerance and diversity in many of the contemporary communities and the attitude that people have toward these issues, we can conclude that religion set in context of inter-religious marriages ${ }^{24}$ is almost diametrically opposed.

${ }^{24}$ E. Gołęiowska, Ethnic and Religious Tolerance in Poland, ,East European Politics and Societies" vol. 23, no. 3, 2009, p. 371-391; L. Lucassen, Ch. Laarman, Immigration, intermarriage and the changing face of Europe in the post war period, „The History of the Family" vol. 14, 2009. 
Approval of inter-religious marriages usually represents merely a declarative rather than real statement of the people, which gives a more or less dominant position to one - usually own, at the expense of the other usually counterpart's religion. Religion seen in context of migrants as something which is ,imported" with them, appears to become conflicting when it is put in context between migrants and ,indigenous" population. Religion is almost always perceived interwoven with local cultures so it bears the marks of the local community, as a creator of the local culture ${ }^{25}$. Religious affiliation of the spouses plays an important role in the Macedonian - Albanian intermarriages. Nevertheless, affiliation to Catholic Christian and Orthodox - Christian religion does not raise any antagonism as it is the case when we talk about intermarriages of spouses from two completely different religions such as Islam and Christianity. In this case religious affiliation becomes an unbridgeable gap.

Oh, no! That can not happen ${ }^{26}$.

The process of acculturation of „,newcomers” within the local community unwinds on many levels. It begins with gradual abandoning of the previous religious norms and customary practices and accepting the local ones. Awareness of such an act although real is not recognized as an essential element within the process of integration and acculturation, however, it becomes a part of the everyday life of the newcomers.

I only follow local customs; there (in Albania) my mother follows their local customs $^{27}$.

Some exceptions has been noted especially during the first year of marriage when in two occasions for the main Christian holidays Christmas and Easter, (for the Catholic as well as for the Orthodox holidays) the wife, prepares traditional and festive local dishes. Therefore for Easter in two occasions she dyes eggs, although for the catholic Ester their number is minimal, which gives the priority of the local religious traditions.

Other local traditional customs associated with weddings, child birth, burials etc. are adapted and practiced very soon by the wives. According to

\footnotetext{
${ }^{25}$ Ibidem, p. 328.

${ }^{26}$ Field research 2010.

${ }^{27}$ Field research 2010.
} 
this situation we can conclude that the barrier or the boundary for intermarriage is set only in cases of completely unknown and completely ,opposite" religions, while in other cases the differences are less significant.

Although the language by itself does not constitute or determine the belonging to a particular ethnic category - group of people or nation, his complementarity is inevitable. If we consider that, the language can act as a symbol of belonging or foreignness, and put into correlation with the will and the motives ${ }^{28}$ of the migrants to integrate into the new society, we could see the resemblance to the elaborated theme of intermarriages of the Albanian and Macedonian population. Ignorance of the language most directly causes problems in everyday communication. Thus, the fluency of the language of the concrete community can be considered as one of the basic integrative or disintegrative elements ${ }^{29}$ that determine an individual belonging to a particular group. Faced with this situation Albanian women - migrants, that intermarried Macedonian men, with the very act of coming to Macedonia undergoes some kind of cultural shock ${ }^{30}$ at all levels - social, religious and linguistic. The period of overcoming this situation and period of adaptation or acceptance of the Macedonian language depends on many factors such as: motivation, degree of education, family and social surrounding etc. With the act of coming into the husbands' home, their mutual communication is almost non-existent. This is due to the fact that the bride only speaks Albanian while her husband only speaks Macedonian language. In very rare cases, with some longer pre-marital period of mutual communication the husband tries to learn the Albanian language by using a dictionary ${ }^{31}$. This situation leads to easier communication with the bride when she enters the new community. In almost all other cases, at the beginning, the basic communication means between the spouses, as well as the rest of the community members, were the hands. Pointing towards some object accompanied with mimicry and loud pronunciation of the

\footnotetext{
${ }^{28}$ H. Esser, ,Migration, Language and Integration” <http://www2000.wzb.eu/alt/aki/ files/aki_research_review_4.pdf>, 16.11.2012.

${ }_{29}$ М.П. Мирчевска, Вербални и невербални етнички симболи во Горна Река, Скопје 2007, р. 133.

30 Л. Макаријоска, Заемките во јазикот на македонските иселеници, „Македонски фолклор", год. XXXIV, no. 66, p. 15.

${ }^{31}$ Field research 2012.
} 
basic words, gave the bride the first cognition of individual words. Promptness of adoption and learning of Macedonian language is merely an individual accomplishment, and it usually lasts about a year. This period is certainly sufficient for acquisition of basic verbal communication while the real knowledge of Macedonian language remains absent. Not even after 67 years do the brides achieve some drastic change in language fluency, but that is probably due to the local community in wider context. However, what is interesting is that all these women have a very subjective attitude towards their own personal achievement of the language knowledge. It has to be emphasized that when it comes to the knowledge of the Macedonian language we discuss the limited knowledge of the local dialect of Macedonian language, rather than any literary knowledge of the language. The absence of the writing and reading skills has been noted among these women, while even if they do know how to read or write, that again is at a basic skill level. Closeness or openness of the nuclear families and their members towards the community or their marginalization, influence the pace of the language fluency of the women as well. In the open family communities where the frequency of communication with the members outside the narrow family circle is much bigger, better speed and fluency in the verbal communication can be noted. Contrary to this case, within closed family communities, where due to established family norms, the communication of the women is restricted and limited to the members of the tight-knit family community, the speed and quality of the verbal communication is at a very low level. This situation is usually the result of quiet family revolt that arises from the way the marriage was concluded and the furtive repulsive attitude toward Albanian brides. In communities where the number of Albanian brides is greater, in the first 2-3 years their mutual communication is in Albanian language, which in the later period this communication becomes a communication with alternative use of Macedonian and Albanian words. Still this type of communication usually takes place when the brides are alone. When in presence of other family or community members, they try to speak only in Macedonian. Recent field researches show that only a limited number of Macedonian - Albanian intermarriages transcend the language barrier as one of the factors for a complete integration and acculturation of Albanian brides, which causes many difficulties for the spouses from both sides. 
Children's bilingualism is basically accepted by both parents although in many cases, up to the age of 3-4, according to the mothers' statements ${ }^{32}$, they communicate with the children in Macedonian language. However, it is natural for the Albanian mother, to speak to her newborns in Albanian as a mother language. Although the largest numbers of children do not speak Albanian very well, their parents confirm that during their stay in Albania they can adapt to the surroundings relatively easy and start using the language. This, again confirms the fact that mothers in the local communities, aside from their statements, communicate with the children in Albanian language as well. In mutual communication the children who originate from this kind of intermarriages, very rarely or never use the Albanian language, which leaves the question open for the real reasons.

$*$

Based on the above we can conclude that the phenomenon of the intermarriages in the past thirty years has become an issue that has been studied in many countries all over the world. Theoretical literature and empirical research confirm that this occurrence is one of a kind challenge that contemporary community faces. In that sense, the main reason for this pilot study is the reality and frequency of Macedonian - Albanian intermarriages in the Republic of Macedonia. Comparison of the examples of theoretical literature and recent field studies in the Republic of Macedonia, show that irrespective of the territory with presence of intermarriages, numerous similarities appear in the context of cause-and-effect relationships and implications arising as a result of the establishment of new connections and relations, which is primarily due to the increased mobility and population movements. Research of the individual phenomena, their comparative analysis and impact on local, national even wider global changes, could not only contribute towards better understanding of the contemporary models of behaviour, but also to the traditional norms and customs passed on by each individual as his own cultural code as well. Based on the concrete empirical data from the initial research of this phenomenon in Macedonia, we can conclude that the reasons are numerous on both sides,

\footnotetext{
${ }^{32}$ Field research 2012.
} 
but yet we can not reach a conclusion if this is an equally spontaneous activity present at both sides or there are some other activities as well. In that sense, it is indicative that the resent study of this phenomenon in Macedonia confirms that the new marital communities as one of a kind structures, represent a symbiosis of socio-cultural and traditional norms, customs, beliefs and symbols that each of the spouses brings to the new community as a „cultural” capital, reshaping oneself and others in the close-knit family frames, but based on the intensity and frequency of the newly established relations with an opportunity to reshape the local communities and other cultural changes that could be expected in the future. 
